\section{Peningkatan Kemampuan Menyimak Melalui Teknik Bisik Berantai}

\author{
Yeherlina Ohe Kokomaking', Misnawaty Usman² \\ Universitas Negeri Makassar
}

Email: yeherlina@gmail.com

Abstrak. Tujuan dari penelitian ini adalah untuk mengetahui peningkatan kemampuan menyimak melalui Teknik Bisik Berantai siswa kelas XI Bahasa SMA PGRI Gelekat Lewo Boru kabupaten Flores Timur NTT. Jenis penelitian ini adalah penelitian tindakan kelas yang terdiri atas dua siklus. Subjek dalam penelitian ini adalah siswa kelas XI Bahasa SMA PGRI Gelekat Lewo Boru. Teknik analisis data dalam penelitian ini terdiri atas data kualitatif dan kuantitatif. Data kualitatif diperoleh melalui observasi dan data kuantitatif diperoleh melalui hasil tes kemampuan menyimak. Instrumen dalam penelitian ini adalah tes yang terdiri atas tes pilihan ganda dan benar-salah. Hasil analisis data menunjukkan bahwa kemampuan menyimak bahasa Jerman dengan nilai yang diperoleh siswa pada siklus I adalah $80,4 \%$ dan siklus II 87,2\%. Data hasil penelitian ini dapat disimpulkan bahwa penerapan teknik bisik berantai meningkatkan kemampuan menyimak bahasa Jerman siswa kelas XI Bahasa SMA PGRI Gelekat Lewo Boru kabupaten Flores Timur NTT.

Kata Kunci: Penelitian Tindakan Kelas, Kemampuan Menyimak, Bisik Berantai
INTERFERENCE

Journal of Language,

Literature,and

Linguistics

\section{E-ISSN: 2721-1835 \\ P-ISSN: 2721-1827}
Submitted
: May $3^{\text {rd }}, 2021$
Accepted
: May $20^{\text {th }}, 2021$

Abstract. The purpose of this study was to determine the increase in listening skills trought the chain whisper technique for students in language XI class at SMA PGRI Gelekat Lewo Boru East Flores NTT. This type ofresearch is a classroom action research which consists of two cycles. The subjects in this study are for students in language XI class at SMA PGRI Gelekat Lewo Boru. The data in this study consisted of qualitative and quantitative data. Qualitative data were obtained through observation and quantitative data were obtained through the results of the listening ability test. The instrument in this study was a multiple choice and true false test. The results of data analysis showed that the listening language with the scores obtained by students in the first cycle was $80.4 \%$ and the second cycle was $87.2 \%$. These results indicate that the application of the chain whisper technique can improve the listening ability for students in language XI class at SMA PGRI Gelekat Lewo Boru East Flores NTT. 


\section{PENDAHULUAN}

Bahasa merupakan alat komunikasi manusia untuk mengungkapkan ide, gagasan, isi pikiran, dan pesan, baik lisan maupun tulisan. Pemerolehan bahasa atau akuisi bahasa adalah suatu proses yang dialami manusia dalam memperoleh kemampuan untuk menangkap, menghasilkan, dan menggunakan kata untuk memahami dan mengkomunikasikan kata tersebut. Ada empat kompetensi berbahasa yakni: kemampuan mendengar (Hörverstehen), keterampilan berbicara (Sprechfertigket), kemampuan membaca (Leseverstehen), dan keterampilan menulis (Schreibfertigkeit). Keempat kompetensi tersebut dapat diperkuat oleh dua aspek lain yakni kosakata (Wortschatz) dan tata bahasa (Grammatik). Antara kompetensi dan aspek bahasa saling berkoheren.

Fokus pada penelitian ini adalah kemampuan menyimak (Hörverstehen) karena kemampuan menyimak merupakan suatu indikator terpenting terhadap keberhasilan siswa dalam belajar bahasa khususnya bahasa Jerman karena semakin banyak dan sering menyimak kosakata, pola kalimat, intonasi, dan sebagainya maka semakin berkembang pula keterampilan berbicara. Untuk dapat berkomunikasi dalam bahasa Jerman, siswa harus mampu memahami dan mereaksi apa yang baru saja dikatakan. Siswa dapat memperoleh kosakata dan gramatikal serta pengucapan yang baik dengan kemampuan menyimak.

Menyimak adalah suatu proses kegiatan mendengarkan lambang-lambang lisan dengan penuh perhatian, pemahaman, apresiasi, interpretasi untuk memperoleh informasi, menangkap isi atau pesan serta memahami makna komunikasi yang telah disampaikan oleh pembicara melalui ujaran atau bahasa lisan. Oleh karena itu, perlu diadakan pengajaran yang memungkinkan siswa dapat menyimak dengan baik materi yang disampaikan dalam pelajaran bahasa Jerman.Hal ini juga tertuang dalam kurikulum 2013 kelas X1 yang harus dicapai dalam kemampuan menyimak yaitu siswa mampu mendengarkan kata, frasa, dan kalimat dengan huruf dan ejaan yang tepat, siswa juga mampu mengungkapkan informasi secara lisan dengan mendengarkan bunyi bahasa, mengidentifikasi, menginterprestasikan, dan mereaksi atas makna yang terkandung di dalammya dalam bentuk kalimat Präsens sederhana dengan kriteria ketuntasan minimal (KKM) yang ditetapkan sekolah SMA PGRI Gelekat Lewo Boru yaitu 76. Berdasarkan hasil observasi yang telah dilakukan pada tanggal 06 Januari 2020 di SMA PGRI Gelekat Lewo Boru serta wawancara terhadap guru bahasa Jerman diperoleh informasi bahwa siswa masih belum memahami isi teks yang diperdengarkan dengan baik. Hal ini disebabkan oleh kurangnya prasarana yang dibutuhkan dalam proses pembelajaran seperti kamus dan buku cetak bahasa Jerman, kurangnya minat siswa terhadap pelajaran bahasa Jerman, serta kurangnya sosialisasi mengenai pembelajaran bahasa Jerman.

Rendahnya hasil belajar siswa dalam kemampuan menyimak didukung oleh hasil penelitian yang dilakukan oleh Selviana, Y., Mannahali, M., \& Dalle, A. (2020) yang meneliti kemampuan menyimak siswa SMA Negeri 13 Bone dengan hasil tingkat kemampuan menyimak siswa berada pada kategori sedang. Penelitian lainnya terkait kemampuan menyimak juga telah dilakukan oleh Usman, M., dkk. (2020); Angreany, F., Saleh, N., \& Mannahali, M. (2021); Pabumbun, A. R., \& Dalle, A. 
(2019) bahwa kemampuan menyimak bahasa Jerman siswa masih dalam kategori sedang. Hal tersebut

Penelitian relevan juga dilakukan oleh Putri (2019) yang meneliti tentang permainan bisik berantai pada keterampilan menyimak bahasa Prancis siswa SMK Negeri 3 Bandarlampung terdapat perbedaan yang signifikan pada hasil belajar kemampuan menyimak siswa yang diajar menggunakan teknik bisisk berantai dengan siswa yang menggunakanan media audio. Penelitian lain yang dilakukan oleh Angela (2012) tentang efektivitas penggunaan teknik permainan bisik berantai dalam pembelajaran keterampilan menyimak bahasa Prancis siswa kelas X SMA Angkasa Yogyakarta menunjukkan adanya perbedaan yang signifikan pada keterampilan menyimak bahasa Prancis antara siswa yang diajar dengan teknik permainan bisik berantai dan siswa yang tidak diajar dengan teknik permainan bisik berantai dengan hasil penelitian menunjukkan adanya perbedaan yang signifikan pada kemampuan menyimak bahasa Prancis antara siswa yang diajar dengan menggunakan teknik permainan bisik berantai dan siswa yang tidak diajar dengan menggunakan teknik permainan bisik berantai

Berdasarkan latar belakang yang telah diuraikan di atas, maka peneliti tertarik untuk melakukan suatu penelitian mengenai penggunaan teknik bisik berantai di tempat yang berbeda, yaitu di SMA PGRI Gelekat Lewo Boru dengan judul "Peningkatan Kemampuan Menyimak melalui Teknik Bisik Berantai Siswa Kelas XI Bahasa SMA PGRI Gelekat Lewo Boru Kabupaten Flores Timur NTT”.

\section{Pengertian Kemampuan}

Kemampuan merupakan kesanggupan menguasai suatu keahlian yang merupakan bawaan sejak lahir atau yang dipelajari untuk melakukan sesuatu. Hasil yang diperoleh dalam menjalani aktivitas tersebut tergantung pada kemampuan yang dimiliki orang tersebut, baik dalam bidang pendidikan maupun dalam bidang lain. Kemampuan adalah sifat yang dimiliki seseorang secara kodrati dan dipelajari, sehingga memungkinkan seseorang untuk menyelesaikan segala pekerjaannya, baik secara mental ataupun fisik dengan baik dan penuh tanggung jawab. Menurut Hacker (1998): “Fähigkeiten verfestigte Systeme verallgemeinerter psychischer Prozesse dar, die den Tätigkeitsvollzug steuern, also Leistung ermöglichen. Die Fähigkeit ist damit eine innere Disposition, die zu einer psychischen Aktivität Anlass geben kann". Artinya kemampuan mewakili suatu sistem dari proses psikologi yang mengontrol suatu kegiatan. Dengan demikian kemampuan merupakan disposisi batin yang dapat menimbulkan aktivitas psikologis. Pendapat yang hampir sama dikemukakan oleh Alwi (2001:707): "kemampuan adalah kesanggupan; kecakapan; kekuatan". Dari beberapa pendapat di atas dapat disimpulkan bahwa kemampuan merupakan kesanggupan dan kecakapan seseorang dalam menguasai keahlian yang merupakan bawaan sejak lahir dengan berusaha secara maksimal yang didukung oleh bakatnya untuk mencapai hasil yang diinginkan.

\section{Pengertian Menyimak}

Menyimak merupakan bagian dari kompetensi berbahasa yang sangat esensial, karena kemampuan menyimak merupakan dasar untuk menguasai suatu bahasa. Usman, dkk (2019:174) mengemukakan: “Menyimak merupakan kegiatan 
yang paling sering dilakukan umumnya ketika berinteraksi dengan orang lain, dimana ketika berkomunikasi, seseorang tentu perlu menyimak dengan baik apa yang sedang diperbincangkan agar terjadi komunikasi”. Saddhono,dkk (2012:11) mengatakan: "Menyimak adalah suatu proses yang mencakup kegiatan mendengarkan, mengidentifikasi, menginterpretasi bunyi bahasa kemudian menilai hasil interpretasi makna dan menanggapi pesan yang tersirat di dalam wahana bahasa tersebut. Jadi, kegiatan menyimak merupakan kegiatan yang disengaja, direncanakan untuk mencapai tujuan tertentu". Seidl (2009:6) mengatakan: "Verständnis von die Fähigkeit ist, die Bedeutung von Wörtern, Sätzen, Satzreihen, und gefügen, von Textsorten zu erfassen (semantische und syntaktische Dimension der Sprachaufnahme) und mit Hilfe des muttersprachlichen Vorwissens die Intention des Sprechers situationsentsprechend zu deuten (pragmatische Dimension)". Artinya menyimak merupakan kemampuan memaknai kata-kata, kalimat, rangkaian kalimat, menangkap/mengerti isi teks (secara semantik dan sintaksis bahasa asli), serta memahami maksud pembicara dari wacana lisan. Hakikat menyimak juga dijelaskan oleh Hermawan (2012:30) bahwa menyimak merupakan sebuah keterampilan bersifat kompleks yang memerlukan ketajaman perhatian, konsentrasi, sikap mental yang aktif, dan kecerdasan dalam mengasimilasi, serta menerapkan setiap gagasan. Dari pendapat para ahli di atas, dapat disimpulkan bahwa menyimak merupakan kegiatan mendengarkan lambang-lambang lisan secara seksama dan menangkap lambang-lambang lisan dengan penuh perhatian, pemahaman, serta apresiasi untuk memperoleh informasi maupun pesan yang terkandung di dalam bahasa lisan tersebut. Usman, dkk (2019:173) berpendapat "Untuk mencapai hasil menyimak yang optimal, dipengaruhi oleh beberapa faktor yakni: perbendaharaan kosakata, media yang digunakan, situasi yang memungkinkan untuk menyimak dengan baik seperti, lingkungan dan pengajar".

Adapun tujuan menyimak adalah untuk menangkap informasi dan pesan yang diungkapkan secara lisan serta untuk memperoleh informasi, menangkap isi, serta memahami makna komunikasi yang disampaikan oleh pembicara melalui ujaran. Terdapat pula tahapan dalam menyimak sebagai berikut: Menurut Tarigan (2008:63) menyimak terdiri atas lima tahapan, yaitu: 1) Tahap mendengar (hearing), dalam tahap ini kita baru mendengar segala sesuatu yang dikemukakan oleh pembicara dalam ujaran atas pembicaranya. 2) Tahap memahami (understanding), setelah kita mendengar maka ada keinginan bagi kita untuk mengerti atau memahami dengan baik isi pembicaraan yang dibicarakan oleh pembicara. 3) Tahap menginterpretasi (interpreting), penyimak yang baik, yang cermat dan teliti, belum puas kalau hanya mendengar dan memahami isi ujaran sang pembicara, dia ingin menafsirkan atau menginterpretasikan isi butir-butir pendapat yang terdapat dan tersirat dalam ujaran itu. 4) Tahap mengevaluasi (evaluating), setelah memahami serta dapat menafsir atau menginterpretasikan isi pembicaraan, penyimak pun mulai menilai atau mengevaluasi pendapat serta gagasan pembicara mengenai keunggulan dan kelemahan serta kebaikan dan kekurangan pembicara. 5) Tahap menanggapi (responding), tahap ini merupakan tahap akhir dalam kegiatan menyimak. 


\section{Penegertian Kalimat}

Kalimat adalah satuan kata yang dapat berdiri sendiri dan mengandung makna atau informasi baik dalam bentuk tulisan maupun lisan yang tersusun dalam pola tertentu. Chaer (2006:327) mengatakan bahwa kalimat adalah satuan bahasa yang berisi suatu pikiran atau amanat yang lengkap yang terdiri dari subjek, predikat, dan objek. Mirwan, M., Mantasiah, R., \& Saud, S. (2020); Andira, A., Hasmawati, H., \& Mantasiah, R. (2020); Fiddienika, A. (2020) bahwa kalimat adalah satuan bahasa terkecil yang dapat digunakan untuk menyampaikan ide atau gagasan dan dapat dikatakan sebagai satuan bahasa terkecil karena sesungguhnya di atas tataran kalimat itu masih terdapat satuan kebahasaan lain yang jauh lebih besar".

\section{Hakikat Model Pembelajaran Kooperatif}

Salah satu model pembelajaran yang bisa menjadi pilihan pengajar untuk digunakan dalam kegiatan pembelajaran di kelas yaitu model pembelajaran kooperatif (cooperative learning) pada mata pelajaran bahasa Jerman. Hal ini juga senada dengan yang diungkapkan oleh Hammoud dan Ratzki (2009:6) "Kooperatives Lernen ist eine strukturierte Form des Lernens, die gleicherrmassen der Erarbeitunf fachbezogener Lerninhalte wie der Einuebung kooperativen Soialverhaltens dient". Pendapat tersebut memberikan arti bahwa, "Pembelajaran kooperatif adalah bentuk pembelajaran terstruktur yang mempunyai fungsi sama yaitu untuk membahas isi pembelajaran secara ilmiah, seperti pelatihan perilaku sosial kooperatif'. Saleh (2017:259) berpendapat “Pembelajaran kooperatif merupakan salah satu model pembelajaran yang mengacu pada teknik pengajaran dimana siswa bekerja sama dalam kelompok untuk meningkatkan hasil belajar". Senada dengan pendapat di atas, Taniredja, dkk. (2013:55) mengemukakan "Pembelajaran kooperatif merupakan sistem pengajaran yang memberi kesempatan kepada siswa untuk bekerja sama dengan siswa lainnya dalam tugastugas yang terstruktur". Ratumanan (2004:130) mengatakan "Dalam pembelajaran kooperatif siswa bekerja sama dalam kelompok kecil saling membantu untuk mempelajari suatu materi". Sejalan dengan pernyataan tersebut menurut Riskayanti, R., \& ; Asri, W. K. (2019); Putri, N. E., Dalle, A., \& Usman, M. (2021); Harianto, H., Dalle, A., \& Anwar, M. (2021) bahwa pembelajaran kooperatif mencakup suatu kelompok kecil maupun besar yang terdiri dari beberapa siswa yang bekerja sebagai tim untuk menyelesaikan sebuah masalah, menyelesaikan suatu tugas atau mengerjakan sesuatu untuk mencapai tujuan bersama-sama". Menurut Hamdayama (2014:64) "Pembelajaran kooperatif merupakan model pembelajaran dengan menggunakan sistem pengelompokan/tim kecil, yaitu antara empat sampai enam orang yang memiliki latar belakang kemampun akademik, jenis kelamin, ras atau suku yang berbeda. Berdasarkan beberapa pendapat para ahli tersebut, dapat disimpulkan bahwa model pembelajaran kooperatif merupakan salah satu bentuk pengajaran yang terstruktur yang lebih menekankan pada kerjasama antarsiswa dalam kelompok dan dapat melahirkan ketergantungan positif, sehingga memunculkan rasa tanggung jawab individu terhadap kelompok serta adanya keterampilan interpersonal dari setiap anggota kelompok dalam memahami materi pembelajaran untuk mencapai tujuan bersama. Terdapat empat 
prinsip model dasar pembelajaran kooperatif yang dijabarkan Hamdayama yaitu (1) prinsip ketergantungan positif, (2) tanggung jawab perseorangan, (3) interaksi tatap muka, (4) partisipasi dan komunikasi. Keempat prinsip tersebut harus diterapkan dalam pembelajaran kooperatif agar mendapatkan hasil yang maksimal.

\section{Hakikat Model Pembelajaran Kooperatif Tipe Bisik Berantai}

Budinuryanta (2008:29) mengatakan teknik bisik berantai adalah guru membisikkan suatu pesan atau informasi kepada siswa. Siswa tersebut membisikkan pesan atau informasi itu kepada siswa kedua. Siswa kedua membisikkan pesan kepada siswa ketiga. Begitu seterusnya secara berantai. Dalam permainan bahasa, teknik bisik berantai dapat digunakan untuk menguji daya simak siswa dan kemampuan untuk menyimpan dan menyampaikan pesan kepada orang lain. Teknik permainan bisik berantai dalam keterampilan menyimak informasi adalah guru membisikkan sebuah kalimat tadi dengan cara membisikkannya ke telinga murid berikutnya. Demikian seterusnya sampai pada murid yang terakhir mengucapkan kalimat tersebut dengan suara nyaring. Boleh juga dituliskan di papan tulis. Lalu guru memeriksa benar tidaknya. Dewi (2014:4) mengatakan bahwa permainan bisik berantai adalah komunikasi antar setiap kelompok agar siswa dapat melatih emosional sosialnya dengan baik. Slamet (2007:24) mengatakan: "Bisik berantai adalah salah satu permainan bahasa dengan cara membisikkan kalimat dari guru ke siswa dan siswa ke siswa berikutnya, sampai siswa terakhir". Berdasarkan beberapa pendapat di atas, maka dapat disimpulkan bahwa teknik bisik berantai adalah salah satu teknik dalam pengajaran yang memperdengarkan suatu kata, frasa, dan kalimat kepada siswa pertama, kemudian siswa pertama membisikkan kalimat tersebut kepada siswa kedua, dan seterusnya hingga siswa terakhir. Kemudian kalimat tersebut diungkapkan kembali lagi kepada gurunya.

Suyatno (2004) berpendapat bahwa: "Permainan bisik berantai bertujuan untuk melatih siswa agar dapat memahami informasi yang dibisikkan oleh temannya dengan cermat, cepat, dan tepat. Sedangkan Faridah (2013) berpendapat bahwa bermain bisik berantai bertujuan untuk menciptakan suasana belajar dari yang pasif ke aktif, dari yang kaku menjadi gerak, dan dari yang jenuh menjadi semangat. Selanjutnya menurut Dewi, dkk (2014) mengatakan tujuan permainan tersebut adalah melatih keterampilan menyimak, kemampuan bahasa, konsentrasi, daya ingat dan interaksi. Berdasarkan pendapat para ahli tersebut maka dapat disimpulkan bahwa tujuan teknik bisik berantai adalah untuk menjadikan siswa agar senang berada dalam kelas, dapat mengajarkan siswa untuk lebih teliti dalam menyimak, siswa dapat belajar berkomunikasi secara lisan yang tepat dan benar, serta dapat memperbanyak perbendaharaan kosakata.

Berikut ini langkah-langkah dalam teknik permainan bisik berantai adalah sebagai berikut: Guru memberikan pengantar singkat tentang pelaksanan teknik bisik berantai; Guru membagi siswa ke dalam lima kelompok. Setiap kelompok terdiri dari lima orang kemudian berbaris dari depan ke belakang begitupun sebaliknya; Guru memutar audio dengan tema die Familie; Guru membisikkan sebuah kalimat präsens sederhana kepada seorang siswa pada setiap kelompok berdasarkan apa yang sudah diperdengarkan melalui audio; Siswa tersebut harus membisikkannya lagi kepada teman di sebelahnya; Siswa terakhir harus mengatakan 
dengan keras kepada guru kemudian menuliskannya di papan tulis; Kelompok yang berhasil mengucapkan kalimat yang benar ialah pemenangnya; dan kelompok pemenang mendapatkan hadiah berupa pujian dan amplop. Adapun kelebihan dari teknik permainan bisik berantai adalah sebagai berikut: Meningkatkan kreativitas siswa dalam proses belajar mengajar; melatih keterampilan bahasa; menarik minat siswa dalam pembelajaran; menimbulkan rasa bahagia dan tanpa beban dalam proses belajar mengajar; dan meningkatkan rasa kerja sama antar siswa. Sedangkan kekurangan pada teknik permainan bisik berantai yaitu: Menimbulkan situasi kelas yang ramai atau riuh; memerlukan waktu yang relatif lama; menimbulkan interaksi yang kurang kondusif antara siswa, guru, dan peneliti; kurangnya daya konsentrasi siswa.

\section{METODE PENELITIAN}

Jenis penelitian ini adalah penelitian tindakan kelas (PTK) atau classroom action research yaitu penelitian yang dilaksanakan dalam kelas dengan tujuan untuk memperbaiki dan meningkatkan kualitas atau mutu pembelajaran agar tercapainya hasil belajar yang lebih baik dari sebelumnya. Model yang digunakan dalam penelitian ini adalah model Kemmis dan Mc Taggart yang terdiri atas beberapa komponen dalam satu siklus, yaitu: perencanaan, tindakan, observasi, dan refleksi. Dalam implementasinya, model Kemmis dan Mc Taggart menggabungkan antara tindakan dan observasi karena kedua hal tersebut tidak dapat dipisahkan. Penelitian ini dilaksanakan pada tanggal 11 September - 28 September 2020 di kelas XI Bahasa SMA PGRI Gelekat Lewo Boru, bertempat di Dusun Wolorona, Desa Hokeng Jaya, Kecamatan Wulanggitang, Kabupaten Flores Timur, Provinsi Nusa Tenggara Timur (NTT). Kode Pos 86253. Kepala sekolah bernama Fransiskus Lamuda S.Pd. Saat ini sebanyak 16 guru yang menjadi pegawai tetap dan 5 guru yang menjadi guru honorer. Terdapat pula 3 jurusan di sekolah tersebut yaitu, jurusan IPA/ MIA (IImu Pengetahuan Alam), IPS/ IIS (Ilmu Pengetahuan Sosial), dan Bahasa/ IBB (IImu Bahasa dan Budaya). Instrumen yang digunakan dalam penelitian ini adalah lembar observasi dan tes hasil belajar siswa untuk mengukur peningkatan kemampuan menyimak siswa setelah mengaplikasikan teknik permainan bisik berantai. Penelitian tindakan kelas ini dilaksanakan dalam 2 siklus dan dilaksanakan secara tatap muka. Setiap siklus dilaksanakan tiga kali pertemuan yang terdiri atas dua kali pembahasan materi dan satu kali tes.

\section{HASIL DAN PEMBAHASAN}

Penelitian tindakan kelas ini dilaksanakan di kelas XI Bahasa SMA PGRI Gelekat Lewo Boru selama dua pekan yang dimulai pada tanggal 11 September - 28 September 2020. Subjek dalam penelitian ini berjumlah 25 siswa. Pertemuan pertama siklus I dilaksanakan pada hari Jumat, 11 September 2020, kemudian dilanjutkan pertemuan kedua siklus I yang dilakasanakan pada hari Senin, 14 September 2020. Sedangkan penelitian tindakan kelas pertemuan pertama siklus II dilaksanakan pada hari Sabtu, 19 September 2020, lalu dilanjutkan pertemuan kedua siklus II yang dilaksanakan pada hari Senin, 21 September 2020, serta evaluasi dilaksanakan pada Jumat, 18 September 2020 untuk siklus I dan Rabu, 23 September 2020 untuk siklus II. Hasil penelitian yang diuraikan berikut ini meliputi hasil 
perencanaan, hasil pelaksanaan tindakan, hasil observasi, dan refleksi serta hasil tes kemampuan menyimak bahasa Jerman siswa. Pada perencanaan peneliti membuat Rencana Pelaksanaan Pembelajaran (RPP) berdasarkan kurikulum 2013 yang berlaku di SMA PGRI Gelekat Lewo Boru sesuai dengan materi yang diajarkan pada semester ganjil, yakni materi die Familie. Selain itu peneliti dan guru berdiskusi mengenai persiapan alat yang berupa laptop, speaker, buku, spidol, papan tulis, pulpen, dan kertas. Sedangkan sumber belajar berupa buku Deutsch ist Einfach 2, manuskrip bahasa Jerman, Internet, YouTube, dan juga langkah-langkah pelaksanaan kegiatan proses pembelajaran, serta langkah-langkah pelaksanaan pembelajaran menggunakan teknik permainan bisik berantai. Media untuk media yang digunakan adalah audio dan video yang disesuaikan dengan materi pembelajaran. Peneliti bersama guru merencanakan bahwa pada saat pelaksanaan pembelajarannya bersifat kolaboratif. Langkah-langkah dalam mengaplikasikan teknik pembelajaran menggunakan bisik berantai antara lain: Guru memberikan pengantar singkat tentang pelaksanan teknik permainan bisik berantai; guru membagi siswa ke dalam lima kelompok. Setiap kelompok terdiri dari lima orang kemudian berbaris dari depan ke belakang begitupun sebaliknya; Guru memutar audio dengan sub tema mein Familienalbum; guru membisikkan sebuah kalimat präsens sederhana kepada seorang siswa pada setiap kelompok berdasarkan apa yang sudah diperdengarkan melalui audio; siswa tersebut harus membisikkannya lagi kepada teman di sebelahnya; siswa terakhir harus mengatakan dengan keras kepada guru kemudian menuliskannya di papan tulis; kelompok yang berhasil mengucapkan kalimat yang benar ialah pemenangnya; kelompok pemenang berhak mendapatkan hadiah berupa pujian dan amplop. Untuk langkah-langkah dalam teknik permainan bisik berantai sama namun dengan sub materi yang berbeda setiap pertemuan, baik dalam siklus I maupun siklus II.

Pada tahap pelaksanaan, mengamati hal-hal yang diperoleh selama proses pembelajaran. Pada pertemuan pertama siklus I, hasil observasi menunjukkan bahwa kegiatan yang berlangsung belum berjalan sesuai dengan rencana karena terdapat beberapa item observasi yang belum dilaksanakan oleh guru dan siswa. Adapun item observasi guru yang belum terlaksana antara lain: guru tidak memberikan kesempatan kepada siswa untuk memberikan komentar, bertanya atau menyampaiakan informasi yang diperoleh dari pelaksanaan teknik permainan bisik berantai; guru tidak memberikan penjelasan atau klarifikasi mengenai kekeliruan yang dilakukan oleh siswa mengenai teknik permainan bisik berantai; dan juga guru tidak membimbing siswa dalam membuat kesimpulan di akhir pelajaran. Sedangkan item observasi siswa yang belum terlaksana antara lain: siswa tidak dalam kondisi siap untuk mengikuti pelajaran; siswa tidak aktif berpartisipasi dalam diskusi kelompok; siswa tidak mengoptimalkan waktu yang diberikan untuk mendiskusikan audio yang telah diperdengarkan; siswa tidak menyimak dengan baik kalimat yang dibisikkan oleh guru dan teman di belakangnya; siswa tidak memberikan komentar, bertanya, dan menyampaikan informasi yang diperoleh dari teknik permainan bisik berantai; Siswa tidak menyimpulkan materi yang telah dipelajari. Pada pertemuan kedua siklus I, hasil observasi menunjukkan bahwa kegiatan yang berlangsung pun belum berjalan sesuai dengan rencana karena terdapat beberapa item 
observasi yang belum dilaksanakan oleh guru dan siswa. Adapun item observasi guru yang belum terlaksana antara lain: guru tidak memberikan kesempatan kepada siswa untuk bertanya mengenai materi Possessivpronomen; guru tidak membimbing siswa dalam membuat kesimpulan di akhir pelajaran; serta guru tidak memberikan tindak lanjut kepada siswa berupa pemberian tugas individu. Sedangkan item observasi siswa yang belum terlaksana antara lain: Siswa tidak menanyakan materi yang belum dipahami; siswa tidak menyimak dengan baik kalimat yang dibisikkan oleh guru dan teman di belakangnya; tidak ada seorang pun siswa yang menyimpulkan materi yang telah dipelajari. Sedangkan pada pertemuan pertama siklus II pelaksanaan proses pembelajaran mengalami peningkatan, karena interaksi guru dan siswa dapat berlangsung dengan baik. Siswa juga terlihat lebih aktif dalam proses pembelajaran. Hal ini terlihat dari terlaksananya aktivitas yang diharapkan dari guru maupun siswa yang terdapat pada lembar observasi, serta antusiasme siswa dalam kegiatan diskusi. Selanjutnya untuk pertemuan kedua pada siklus II, pelaksanaan pembelajaran dengan menerapkan teknik pembelajaran bisik berantai telah dilaksanakan dan berjalan dengan baik. Berdasarkan data yang telah diuraikan di atas, keaktifan dan hasil kemampuan menyimak siswa telah mengalami peningkatan dari siklus I ke siklus II, sehingga tidak perlu dilakukan tindakan lebih lanjut karena telah mencapai tingkat keberhasilan peneliti dan guru dalam menerapkan teknik bisik berantai. Diketahui bahwa kosakata siswa semakin banyak, proses pendengar, pengucapan, dan pelafalan dalam hal penyebutan huruf umlaut dan vokal rangkap juga semakin baik, sehingga siswa sudah memiliki kemampuan yang baik dalam menyimak kalimat präsens bahasa Jerman.

Berdasarkan hasil pengamatan tersebut, diperoleh informasi mengenai adanya peningkatan kegiatan belajar siswa kelas XI Bahasa SMA PGRI Gelekat Lewo Boru kabupaten Flores Timur NTT melalui teknik bisik berantai. Peningkatan belajar tersebut terlihat dari antusiasme dan semangat belajar siswa yang meningkat setiap pertemuan, hal ini dikarenakan prosedur pembelajaran teknik bisik berantai yang telah diketahui dengan baik oleh guru dan siswa, sehingga proses pembelajaran berlangsung sesuai harapan. Keberhasilan proses pembelajaran dengan teknik bisik berantai tersebut dibuktikan oleh hasil belajar siswa pada kemampuan menyimak bahasa Jerman, yakni capaian hasil belajar siswa kelas XI Bahasa SMA PGRI Gelekat Lewo Boru pada siklus I sebesar $80 \%$, sedangkan pada siklus II mengalami peningkatan sebesar $85 \%$. Hasil kemampuan menyimak bahasa Jerman siswa secara keseluruhan berdasarkan kriteria penilaian aspek komunikatif dan aspek ketetapan bahasa pada siklus I yaitu $80,4 \%$ sedangkan pada siklus II mengalami peningkatan dengan selisih 6,8 poin yakni $87,2 \%$.

\section{KESIMPULAN}

Berdasarkan hasil penelitian tersebut dapat disimpulkan bahwa penelitian mengenai Peningkatan Kemampuan Menyimak Kalimat Präsens melalui Teknik Bisik Berantai Siswa Kelas XI Bahasa SMA PGRI Gelekat Lewo Boru Kabupaten Flores Timur NTT dapat dikatakan "meningkat". 


\section{DAFTAR PUSTAKA}

Alwi,Hasan et.Al. (2001). Kamus Besar Bahasa Indonesia.Jakarta:Balai Pustaka.

Andira, A., Hasmawati, H., \& Mantasiah, R. (2020). PENERAPAN MODEL PEMBELAJARAN KOOPERATIF TIPE STAD (STUDENT TEAM ACHIEVEMENT DIVISION) DALAM KETERAMPILAN MENULIS KALIMAT SEDERHANA BAHASA JERMAN. Interference: Journal of Language, Literature, and Linguistics, 1(2), 128-133.

Angela, Jilly. (2012). Efektivitas Penggunaan Teknik Permainan Bisik Berantai Dalam Pembelajaran Keterampilan Menyimak Bahasa Prancis Siswa Kelas X SMA Angkasa Yogyakarta. (skripsi). Universitas Negeri Yogyakarta (UNY). Yogyakarta.

Angreany, F., Saleh, N., \& Mannahali, M. (2021, March). YouTube-Based Audio Visual Media in German Listening Learning. In International Conference on Science and Advanced Technology (ICSAT).

Budinuryanta Y, dkk. (2008). Pengajaran Keterampilan Berbahasa. Jakarta: Universitas Terbuka.

Chaer, Abdul. (2006). Tata bahasa praktis bahasa Indonesia. Jakarta.: PT Asdi Mahasiswa.

Dewi, A. K. (2014). Penerapan Model Pembelajaran Cooperative Script Melalui Permainan Bisik Berantai untuk Meningkatkan Perkembangan Berbahasa pada Anak. Jurnal Pendidikan Anak Usia Dini.

Faridah Kartono. (2013). Peningkatan Kemampuan Menyimak Menggunakan Teknik Permainan Bisik Berantai di Kelas V Sekolah Dasar Negeri 19 Sungai Pinyuh. Artikel Penelitian Universitas Tanjung Pura Pontianak.

Fiddienika, A. (2020). ADJECTIVE PHRASES IN THE PREFACE OF AL-MUNJIDU DICTIONARY FIRST PRINTING WORKS LOUIS MA'LŪF AL-YASŪ'I: SYNTAX ANALYSIS. Interference: Journal of Language, Literature, and Linguistics, $1(1)$.

Hacker, W. (1998). Allgemeine Arbeitspsychologie. Bern: Huber.

Hamdayana, Jumanta. (2014). Model dan Metode Pembelajaran Kreatif dan Berkarakter. Jakarta: Ghalia Indonesia.

Hammoud, Antje dan Ratzki, Anne. (2009). Fremdsprache Deutsch Kooperatives Lernen. München: Max Heuber Verlag.

Harianto, H., Dalle, A., \& Anwar, M. (2021). Pengaruh Pembelajaran Kooperatif dan Gaya Belajar Terhadap Keterampilan Menulis Bahasa Jerman Mahasiswa. Interference: Journal of Language, Literature, and Linguistics, 2(1), 49-56.

Hermawan, H. (2012). Menyimak Keterampilan Berkomunikasi Yang Terabaikan. Yogyakarta: Graha Ilmu.

Mirwan, M., Mantasiah, R., \& Saud, S. (2020). PENGUASAAN KATA SANDANG BAHASA JERMAN SISWA SMA NEGERI 3 SINJAI DALAM MENYUSUN KALIMAT SEDERHANA. Interference: Journal of Language, Literature, and Linguistics, 1(1).

Pabumbun, A. R., \& Dalle, A. (2019). Problematika Pembelajaran Kemampuan Menyimak Bahasa Jerman Siswa Kelas XI SMAN 11 Makassar. Eralingua: Jurnal Pendidikan Bahasa Asing dan Sastra, 1(2). 
Putri, M. (2019). PERMAINAN BISIK BERANTAI PADA KETERAMPILAN MENYIMAK BAHASA PRANCIS SISWA SMK NEGERI 3 BANDARLAMPUNG.

Putri, N. E., Dalle, A., \& Usman, M. (2021). Keefektifan Model Pembelajaran Kooperatif Tipe Picture And Picture dalam Penguasaan Kosakata Bahasa Mandarin Siswa. Interference: Journal of Language, Literature, and Linguistics, 2(1), 18-26.

Ratumanan, T.G. (2004). Belajar dan Pembelajaran. Surabaya: University Press.

Riskayanti, R., \& Asri, W. K. (2019). Keefektifan Model Pembelajaran Kooperatif Tipe Tea Party dalam Keterampilan Berbicara Bahasa Jerman. Eralingua: Jurnal Pendidikan Bahasa Asing dan Sastra, 3(1).

Saddhono, Kundharu dan Slamet. (2012). Meningkatkan Keterampilan Berbahasa Indonesia (Teori dan Aplikasi). Bandung: CV. Karya Putra Darwati.

Saleh, N. (2017). Efektivitas Model Pembelajaran Tipe Paired Storytelling dalam Keterampilan Berbicara Bahasa Jerman Siswa Kelas XI SMAN 11 Makassar. Prosiding Seminar Nasional LP2M UNM. Makassar. Hal. 259.

Seidl, Linda. (2009). Hörverstehen in Theorie und Praxis. GRIN Verlag. Norderstedt Germany. Diakses pada tanggal 24 Januari 2015 dari Word Wide Web: (www.books.google.de).

Selviana, Y., Mannahali, M., \& Dalle, A. (2020). HUBUNGAN ANTARA PENGUASAAN KOSAKATA DENGAN KEMAMPUAN MENYIMAK BAHASA JERMAN SISWA KELAS XI BAHASA. Interference: Journal of Language, Literature, and Linguistics, 1(2), 148-152.

Slamet. (2007). Dasar-dasar Pembelajaran Bahasa dan Sastra Indonesia Di Sekolah Dasar. Surakarta. Sebelas Maret University Press.

Suyatno. (2014). Teknik Pembelajaran Bahasa dan Sastra. Surabaya: SIC

Taniredja, dkk. (2013). Model-model Pembelajaran Inovatif dan Efektif. Bandung: Alfabeta.

Tarigan, H. G. (2008). Menyimak sebagai Suatu Keterampilan Berbahasa. Bandung: Angkasa.

Usman, M., Dalle, A., Azizah, L., \& Ernawati, E. (2020). EFEKTIVITAS PENGGUNAAN LABORATORIUM BAHASA DALAM PEMBELAJARAN KETERAMPILAN MENYIMAK BAHASA JERMAN MAHASISWA PRODI PENDIDIKAN BAHASA JERMAN FBS-UNM. Interference: Journal of Language, Literature, and Linguistics, 1(1).

Usman, Misnawaty, dkk. (2019). Pengaruh Media Audio terhadap Kemampuan Menyimak Bahasa Jerman Mahasiswa Program Studi Pendidikan Bahasa Jerman Universitas Negeri Makassar. Indonesian Of Journal Education Studies (IJES). Makassar. 